\title{
MONITORING THE IMPACT OF LAND REFORM ON QUALITY OF LIFE: A SOUTH AFRICAN CASE STUDY *
}

\begin{abstract}
This paper outlines the approach that is utilized by the Monitoring and Evaluation directorate of the Department of Land Affairs (DLA) in South Africa in assessing the quality of life for the land Reform beneficiaries. The paper begins with an overview of the three Land Reform programs in South Africa. The paper then moves on to outline the original design for monitoring and evaluating the quality of life for land reform beneficiaries. It then proceeds to detail the current Monitoring and Evaluation design being utilized, highlighting its strengths and weaknesses. The last section discusses some of the findings of the quality of life study undertaken in 1999.
\end{abstract}

\section{INTRODUCTION}

In 1994 the first democratically elected government of South Africa committed itself to the Reconstruction and Development Programme (RDP), the policy framework through which it was hoped, a broad transformation of South African society could be achieved. The overall goal of the RDP was the promotion of a fundamental transformation of the social, economic and moral foundations of South African society (ANC, 1994; GNU, 1994). Moreover, the RDP was seen to be a statement of intent, not only for government but also for other sectors of South African society, including the private sector, Non Government Organisation's (NGOs) as well as local communities. Land reform is the third element of South Africa's RDP policies that focuses on targeted transfers, the others being a housing grant and a suite of welfare transfers including state pensions and child support.

Compared to land reform programmes in other countries, many of which are focused more on productive development, the South

* A revised version of a paper presented to the International Society for Quality of Life Surveys conference, Girona, Spain, 20-22 July 2000.

Social Indicators Research 58: 293-312, 2002.

(C) 2002 Kluwer Academic Publishers. Printed in the Netherlands. 
TABLE I

Rural Poverty in South Africa (1995)

\begin{tabular}{llr}
\hline Indicator & $\begin{array}{l}\% \text { of } \\
\text { population }\end{array}$ & $\begin{array}{l}\text { Estimated } \\
\text { population }\end{array}$ \\
\hline Poverty rate - total & 49.9 & 19700000 \\
Poverty rate in non-urban areas & 70.9 & 13700000 \\
Poverty rate in urban areas & 28.5 & 6000000 \\
Poverty share of non-urban areas & 71.6 & \\
African poverty rate & 60.7 & 18300000 \\
White poverty rate & 1.0 & 44000 \\
Unemployment rate & 29.3 & 4250000 \\
Income share of poorest 40\% of households & 11.0 & \\
National Gini co-efficient & 0.52 & \\
\hline
\end{tabular}

African programme has places a strong emphasis on equality and the redress of historical inequities. In the formulation of policy, attention has been paid to the interests of the rural poor generally, and the interests of rural women in particular. The appropriateness of this approach has been the subject of considerable debate (van Zyl et al., 1996; Levin and Weiner, 1997; Lipton, Ellis and Lipton, 1996). To the extent that access to land improves the well-being of poor households, the poverty profile of South Africa shown in Table I lends support to this emphasis. While approximately half of South Africa's total population of 40 million people can be categorised as being poor, most of the poor live in rural areas of South Africa, with the poverty share of rural areas (i.e. the percentage of poor individuals that live in rural areas) being equal to $72 \% .{ }^{1}$ The poverty rate in rural areas (i.e. the percentage of individuals classified as poor) is about $71 \%$, compared with $29 \%$ in urban areas. This high poverty rate is combined with deep levels of poverty among the poor in rural areas. Consequently, rural households account for $76 \%$ of the total poverty gap, which measures the severity of poverty, although they only make up $50 \%$ of the population.

Despite the potential offered by land reform for improving the quality of life in rural communities, and an improvement in the delivery performance of government in recent years, the land 
reform initiative is currently under review. Information provided by the monitoring and evaluation of the programme can potentially assist the review process. Monitoring and evaluation (M\&E) has become an important aspect of all policy analysis in South Africa and provides both insight into management and implementation processes, as well as the effectiveness of targeting and the provision of support. This has been recognised by the Land Reform Programme since the first planning exercises were initiated and $\mathrm{M} \& \mathrm{E}$ has been implicit in the programme since its inception. This paper uses the third land reform monitoring study undertaken since the introduction of the policy in 1994 as a case study to show how the quality of life of land reform beneficiaries is evaluated. Although many of the premises for monitoring remain consistent, the study represents a departure from the previous $M \& E$ system through its use of a single integrated instrument for the collection of data, a more complex sampling procedure, and the manner in which the data was collected.

\section{THE LAND REFORM PROGRAMME IN SOUTH AFRICA}

In being operationalised, the land reform programme has been broken into three elements: redistribution, restitution and tenure reform.

- Restitution: The goal of the restitution policy is to restore land and provide remedial options to people dispossessed by past racially discriminatory legislation and practises. Cases are dealt with through the Land Claims Court and Commission, established under the Restitution of Land Rights Act of 1994. Eligible cases are largely the victims of forced removals since 1913. The vast majority of restitution claims are still pending, either with the Commission on the Restitution of Land Rights, or with the Land Claims Court.

- Tenure reform seeks to improve tenure security for previously disadvantaged people of South Africa. This programme includes a review of current land policy, administration and legislation with a view to accommodating more diverse forms of land tenure. Tenure reform was still proceeding by way of pilots or test cases in 1999. 
- Redistribution was established with the aim of providing opportunities for the large number of black households who wanted to access land but did not have specific documentation to prove that their ancestors were forcibly dislodged or who were not immediate beneficiaries of programmes of tenure reform. The programme provides a grant of $\mathrm{R} 16000$ (originally R 15000 ), equal to the national housing subsidy that can be used by rural households to acquire land in the regular market. This is expected to provide these households with the means to establish their own productive enterprises.

Of the three branches of the Department of Land Affairs' land reform programme, tenure reform is likely to have the most farreaching consequence due to the large numbers of people involved. Although no reliable figures exist as to how many people have insecure land rights, it can be surmised that most of those living in the former 'homeland' areas can be characterised as having insecure tenure. This amounts to some 3,9 million black rural households. In addition, there are presently around 1,3 million households living in informal and squatter housing in and around urban areas, and roughly 800,000 permanent farmworkers and their on-farm households whose lodging is only as secure as their jobs. This yields a rough sum of around 6 million households. However, the legislative reforms required for tenure reform has yet to be finalised, and there has been little progress in the implementation of this policy.

By contrast, land redistribution is to affect about 1,5 million households over the next ten years. The initial land reform target for the redistribution programme was massive - to transfer $30 \%$ of South Africa's 99 million hectares of farmland, or about 30 million hectares, between 1994 and 1999. After the first three years of operation, about 200000 hectares of land have been transferred to about 20000 households. This represented $0.6 \%$ of the target, and $0.2 \%$ of the households demanding land. However, as Table II shows, even with a moratorium imposed on land reform projects during 1999, there has been a rapid increase in both the number of projects and the number of beneficiaries. ${ }^{2}$ By the end of 1999 there were some 26000 households involved in 245 land reform projects. This represents a ten-fold growth from the 245 households 
TABLE II

Growth of Land Redistribution Transfers

\begin{tabular}{ccc}
\hline Year & Number of projects & Number of households \\
\hline 1995 & 1 & 245 \\
1996 & 29 & 4977 \\
1997 & 39 & 7133 \\
1998 & 90 & 7609 \\
1999 & 86 & 6390 \\
Total & 245 & 26354 \\
\hline
\end{tabular}

that received land during 1995 and had risen to 36394 households using 684914 hectares by October, 2000.

Finally, land restitution, which is mandated by the Constitution, is unlikely to affect more than 500000 households, both urban and rural, over the same amount of time. Due to the complex legal processes involved, although 67500 cases had been lodged by October, 2000, just on 8288 cases affecting 20473 households had been resolved.

\section{MONITORING AND EVALUATION OF LAND REFORM IN SOUTH AFRICA}

The original design for monitoring and evaluation (M\&E) was based on a series of questionnaire formats, each of which covered a different aspect of the Land Reform Programme. These were developed during 1994 through a series of workshops convened by the Land and Agricultural Policy Centre (LAPC). ${ }^{3}$ The system that was developed focused on two main elements:

- Measurement of the quality of life enjoyed by land reform beneficiaries. A household questionnaire was developed for this purpose;

- Assessment of the targeting and equity components of the land reform programme as a whole. A community level questionnaire was developed for this purpose supported by an on-line management information system. 
A number of other Formats were also developed as supporting instruments, including environmental impact studies, land demand and supply, and land invasions.

While this system was first implemented in 1996, it was only in October/November, 1997 that the first comprehensive and systematic study was undertaken. A total of 62 land reform projects was surveyed, but information was collected for only 217 households. In May 1998, the Monitoring and Evaluation Directorate of the Department of Land Affairs (DLA) completed the Quarterly Land Reform Monitoring Report. An independent assessment of the report concluded that, in addition to a number of implementation problems, the information collected was not sufficiently detailed to permit the type of evaluation analysis required by DLA.

In July 1998, the Monitoring and Evaluation Directorate decided that the Quality of Life instruments previously utilised to monitor and evaluate the progress and impact of the land reform programme would be rationalised. In line with this decision, the previous system of multiple formats was replaced by a single integrated system with two data gathering instruments:

- A revised and expanded household survey to collect quality of life data based on the Living Standards Measurement Surveys implemented in many countries by the World Bank (Grosh and Munoz, 1996). The purpose of this questionnaire was to investigate the individual and household characteristics of land reform beneficiaries;

- A new community questionnaire to collect information concerning the diverse projects that have been established by the land reform programme as well as data concerning community level attributes. This questionnaire also collected price data to facilitate the calculation of a community specific price index.

The redesign of the instruments was undertaken in collaboration with the Monitoring and Evaluation (M\&E) directorate and a Technical Advisory Group (TAG) of land reform specialists. Fieldwork was undertaken between August and October, 1999, and after extensive cleaning of the data, the first revised Quality of Life report has been completed and submitted to the DLA. 


\section{FRAMEWORK FOR ANALYSIS}

The conceptual framework that underpins the redesigned M\&E system for land reform in South Africa is grounded on four elements. Together these reflect not just a concern for measuring improvements in the 'standard of living' of land reform beneficiaries, but following Dreze and Sen (1989: p. 13), also of assessing the effect of the land reform on the capabilities of beneficiaries in their productive and social lives.

Food security is the first element of the framework and is an important determinant of well-being directly affected by land reform. This can be through a direct relationship such as the growing of food or cash crops that are either eaten by the household or traded. Well-being may also be affected through an indirect relationship when, because of access to secure tenure, households are able to reallocate their income towards greater food security, receive services and invest in improved shelter. This in turn, improves their health, enhances their quality of life and frees up time for productive activities (Chambers, 1988).

Secondly, although the mandate of the DLA does not extend to the provision of services, such as water and electricity, and facilities, such as schools and clinics, these are central determinants of the physical quality of life of land reform beneficiaries. As a result, these are thought to be sufficiently important for inclusion into the DLA M\&E system as indirect outcomes from land reform.

Another aspect of the land reform policy relates to the formation of different types of land management committees. The functioning of these associations is critical not only to the effective use of the land that is transferred, but also to the ability of the community to mobilise and organise for the delivery of services. Further, although difficult to measure, empowerment is an important outcome that is sought by the land reform programme. Institutional capacity is thus key both as on outcome of development, and as a mechanism for the facilitation of development.

Finally, while agriculture is not the sole, nor even the most important, activity that is addressed by land reform, the particular form taken by the South African land reform programme demands that agricultural activities be examined in detail. At a general level, land reform is concerned with the regeneration of an 
agrarian economy, of which agriculture, whether for subsistence, for exchange or as a source of employment, is an important component. At a specific level, the anticipated comparative competitiveness of small-scale farmers over larger scale farming activities is central to the logic of a market-assisted land reform such as that adopted in South Africa (van Zyl and Kirsten, 1997: pp. 180-182).

The South African land reform programme has adopted a targeted approach in its implementation, and thus an additional concern for $M \& E$ relates to the effectiveness of the targeting mechanisms. Generally targeting may carry two error types:

1. people are excluded as beneficiaries who should be included, in other words, failure to reach those from whom the intervention is primarily intended;

2. people are included as beneficiaries who should be excluded, in other words, excessive coverage whereby groups not intended as beneficiaries received assistance from the intervention (Cornia and Stewart, 1995: p. 351).

For this reason, a beneficiary profile is a necessary component of the M\&E strategy, and, wherever possible, a comparative analysis with non-beneficiaries should be included.

\section{QUESTIONNAIRE DESIGN}

In translating this analytical framework into a survey instrument, both the household and community questionnaires have been structured to examine three themes. Different modules are used to collect information within these themes which combine objective and subjective measurements:

- Project, community and household composition;

- Project and household income, livelihoods and well-being;

- Project, community and household institutional involvement, satisfaction and expectations.

Composition of the household is tracked as a means of checking the representivity of the sample against large sample official statistics, as well as to monitor changes in project, community or household composition that might arise due to the land reform. Well-being measures monitor longer-term trends in the economic and social 
status of the beneficiaries. Within this theme, livelihood indicators show the various activities that the project or household engage in, and stresses activities, such as agricultural production, in which land is a productive input. Finally, satisfaction indices track the institutional structures and involvement of beneficiaries, the beneficiaries' short-term views concerning the processes that are followed and the beneficiaries' views of the changes in well-being that they anticipated when entering the programme.

The size, structure and demographic composition of the household was collected by means of a standard household roster. The information collected includes age, gender, occupational status, residence and education. In addition, the relationship of each household member to the main decision-maker or household head, as well as to the land titleholder has been identified. In the case of the community questionnaire, the number and composition of households in the various community projects has been collected, along with movements onto and from the project.

The well-being theme of the household questionnaire tracks different aspects of the quality of life of the household. Several modules have been used, with household income being tracked by means of a simple expenditure module and a livelihoods module which includes shares in joint production schemes. The expenditure component permits the calculation of a money-metric measure of well-being, that is measurements expressed in a unit of currency. The argument behind such measures is that these best reflect the economic well-being of the household by measuring the ability of the household to purchase the commodities and services required for some minimum standard of living. The arguments against such measurement include the fact that not all requirements for an acceptable quality of life can be purchased (for example justice, freedom from violence), that some requirements may be met through recourse to common property (water, wood fuel), and that this measure looks at the inputs to a satisfactory quality of life rather than the outcomes (such as health, education and so forth). Despite these problems, money-metric measures are widely used and are readily understood (Lipton and Ravallion, 1997).

Agricultural production has received detailed attention to investigate the productive use to which land has been put. Household 
wealth has been tracked by collecting information on assets, savings and debt, and by using the education data collected in the household roster. Access to services has been tracked looking at a check list of important services and assessing access, quality and reliability of each of the following:

- School

- Health facilities

- Energy

- Extension

- Telecommunications
- Transportation and roads

- Water and sanitation

- Credit

- Markets services

Household empowerment was examined by looking at the following indicators, especially for women:

- Knowledge of institutions - Involvement in institutions

- The functioning of land administration authority

The security of household land rights has been traced by listing the various land plots to which the household might have rights, and then examining whether these rights are exercised, how they were acquired, whether they can be traded or leased. The following is examined:

- Land use rights

- Grazing

- Residential
- Commercial

- Arable

This section also examines why some households do not exercise the land rights that they do have.

The community questionnaire considers a similar set of indicators, although in the case of income and livelihoods, only the income and activities generated by community projects is gathered. It should be noted that the projects established under the land reform programme have assumed many different organisational structures. Sometimes these have involved group land allocation (and production), while in other cases individual land allocations have been adopted, while a mix of both forms of allocation is also possible. 
Similarly, projects vary in terms of their purpose, with some being only for settlement, while others are equity share schemes with the clear objective of profit maximisation.

The satisfaction indices consider two dimensions. Firstly, satisfaction with the process followed by DLA and the land administration body during the transfer, as well as in the post-transfer stage (after-care). Secondly, respondents were asked about their expectations of the land reform programme in terms of livelihoods, access to services, and empowerment.

\section{RESEARCH DESIGN}

The research design consists of a baseline survey in 1999 in which both household and community questionnaire have been administered. The sampling frame included all beneficiaries of the land reform programme who joined the programme up until December1998. Further to this, the sample that was drawn was stratified in such a way that the beneficiaries between January 1998 and December 1998 can be analysed separately from the previous years. In 2000 and 2001, it is envisaged that the household questionnaire will be administered to a sample drawn from the beneficiaries of projects that commenced in 1999 and 2000 respectively. However, the community questionnaire will be undertaken in all projects that have been sampled for the current and previous years. In 2002, and each year thereafter, both questionnaires will be administered to a sample of new projects as well as to the sample from three years prior, thus forming a panel or longitudinal study. Community questionnaires will still be administered to the remaining sample. Conceptually, this approach may be represented as in Figure 1.

This research design has a number of advantages. Firstly, information collected at the community level, such as the operation and income generated by communal project, can be integrated into the household data. Furthermore, targeting of land reform can be analysed by comparing the beneficiary profile drawn from different years. In each case, the new group is drawn randomly, thereby enabling a probability sample to develop in the face of an expanding universe. Analysis of the quality of life of land reform beneficiaries can be tracked by comparing the results of the community question- 


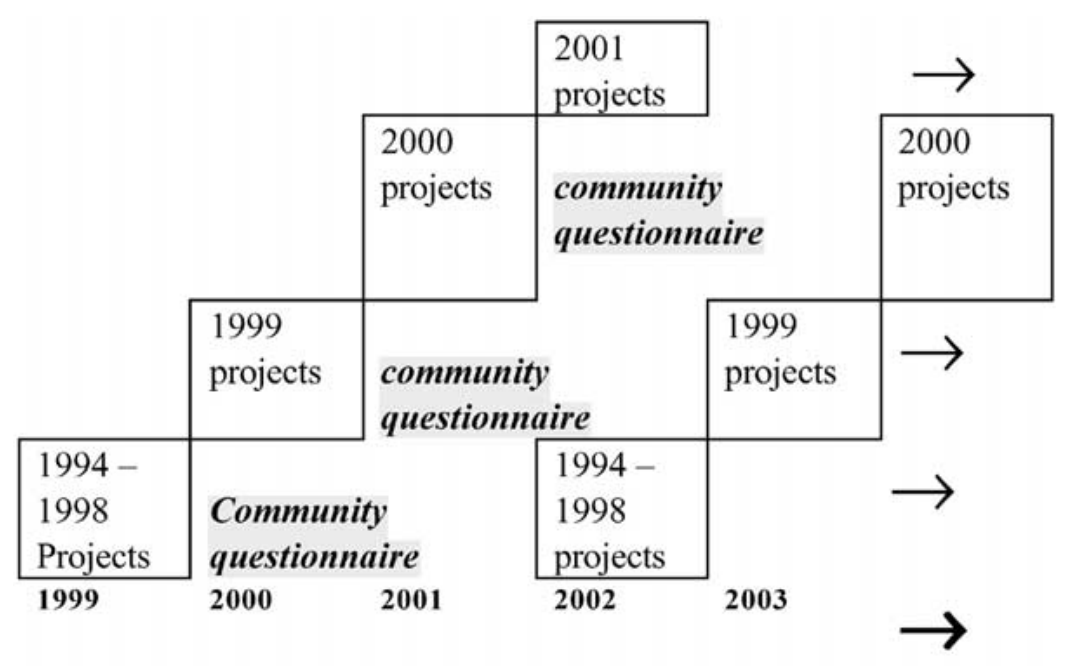

Figure 1. Sample design: 1999-2001.

naire that are completed each year. Since this questionnaire will be administered to all existing and new projects each year, analysis of the changes in quality of life that are experienced by communities in the land reform programme can take place in 2001, and every year thereafter. Analysis of quality of life changes at the household level can be assessed from 2002 as the households from each wave are resurveyed.

There are a number of technical advantages as well. Due to the existence of panel data, future analysis will be able to take into account the effect of time-invariant household fixed effects. These include unobserved characteristics of households, such as willingness to innovate, which might lead to changes in their quality of life that are not attributable to land reform. Panel data also improves the precision of the results since data are collected from more than one time period allowing enumerator and respondent errors to be identified. Finally, the attrition rate of the household sample can be reduced, since information on migration can be collected during the implementation of the annual community questionnaire. ${ }^{4}$

The design has at least one important shortcoming. In each of the first three years of data collection, an impact assessment of the land reform can be only tentatively undertaken at the household level. This is because households will only just have established themselves after the transfer of land, and it is unlikely that the benefits 
from increased agricultural or non-agricultural production will have been realised. Likewise, it will not be possible to identify failure to improve quality of life. However, at the project level, some analysis of the impact of the land reform will be possible after the first wave of data collection.

\section{SUMMARY OF FINDINGS}

In terms of the capabilities based framework discussed earlier, Table III summarises the key findings of the study. Food security is one the most important determinants of well-being that could be directly affected by land reform. The data show that the basic headcount ratio or incidence of poverty for the sample is $78 \%$, while the headcount using a lower poverty line, indicating extreme or ultra poverty, stands at $47 \%$. These levels are exceedingly high relative to other poverty estimates for South Africa. For example, Klasen (1997) estimates from the 1993 Saldru study that South African poverty rates range between 44 and $57 \%$. This would seem to indicate that households involved in land reform projects are relatively poorer than the national average. In addition, the data also reveal that the depth of poverty (measured by the poverty gap ratio) is higher for land reform beneficiaries that for the South African population as a whole.

These high levels of poverty among land reform beneficiaries confirms that this is a group in need of more secure access to assets and the livelihoods that these might bring (Carter and May, 1999). The results of the study do suggest that the land reform programme is making a contribution in this regard. When the value of agricultural production is subtracted from household expenditure, the incidence of poverty increases to $79 \%$ and more importantly, there is an increase in the percentage of the sample who are ultrapoor to $49 \%$ as well as a sharp increase in the severity of poverty as measured by the poverty gap ratio. ${ }^{5}$ Furthermore, twenty five different kinds of crops were listed as being grown by the land reform beneficiaries, with most households growing multiple crop types. Over $67 \%$ of those who were growing crops cultivated two or more items, and $20 \%$ growing four or more items. The implication is that agricultural production is an important source of income to 
TABLE III

Key Indicators of Quality of Life

\begin{tabular}{lr}
\hline Indicator & $\%$ \\
\hline Headcount Ratio, PL = R476.30 per adult equiv. & 78.4 \\
Headcount Ratio UPL = R238.19 per adult equiv. & 47.2 \\
\% female head & 31.0 \\
\% female land grant holder & 45.1 \\
\% adult illiteracy (less than 5 years education) & 26.5 \\
\% with piped water to property & 45.4 \\
\% with flush toilet or improved pit latrine & 33.1 \\
\% connected to electricity & 42.2 \\
\% with access to conventional phone & 19.4 \\
Mean landholding (ha) & 89.7 \\
Median landholding (ha) & 0.5 \\
\% with land for agricultural purposes & 70.3 \\
\% who cultivated crops & 33.7 \\
Community meeting held monthly or more often & 65.2 \\
Regular report backs from committee & 47.4 \\
\% who don't know whether land grant fully used & 68.3 \\
People trust each other over most things & 52.5 \\
Moderate or severe conflict in the community & 13.4 \\
\% realised expectation to plant crops & 21.9 \\
\% realised expectation to have a better home to live in & 14.5 \\
\hline very unhappy or unhappy with land reform & 15.8 \\
\hline
\end{tabular}

the very poor, which boosts the income of this group but in 1999 was still not sufficient to raise them out of poverty.

It is noteworthy that $75 \%$ of land redistribution beneficiaries have access to more than one plot of land, usually a residential plot and a plot for production while just over $70 \%$ of sampled households currently have access to a plot of land for the cultivation of crops. ${ }^{6}$ Overall, grazing is the most commonly found productive form of land use. Using these data to explore possibilities for fostering sustainable growth by simultaneously improving equity and effi- 
ciency, Deininger and May (2000) conclude that although the South African land reform program has not lived up to the quantitative goals set, the programme has led to a significant number of economically successful projects that have already generated sustainable revenues. These projects have involved significantly larger shares of poor people than less viable projects, suggesting that increased access to productive assets could be an important path to poverty reduction.

However, much land remains under-utilised with neither grazing nor cultivation occurring. It is also disturbing that the data show that women-headed households are less likely to use land for production than male-headed households. The specific constraints faced by women on land reform projects may require further investigation. The data does suggest that there are opportunities for income generation that are being missed. For example, more households are holding land that is fallow or vacant than renting out their land for others to use.

Services are an indirect outcome from land reform. Despite the high levels of unfulfilled expectations, the land reform beneficiaries enjoy comparatively high levels of services when compared to African rural households as a whole. ${ }^{7}$ Land reform beneficiaries are located farther from reliable transport networks but have better access to means of communication and services. A greater proportion of households have electricity connections, access to piped water and access to telecommunications than is the case reported by the October Household Survey 1997. However, in terms of the quality of housing, as measured by the type of building materials and number of rooms, land reform beneficiaries perform less well. In many ways this is not surprising since a time lag is inevitable before new houses can be fully constructed, and it is to be expected that this situation will improve over time. Finally, there is provincial variation, suggesting that land reform projects are better integrated into service delivery programmes in some areas than in others, and that improvements are possible in certain provinces.

The functioning of land management committees and other local associations is critical not only to the effective use of the land that is transferred, but also to the ability of the community to mobilise and organise for the delivery of services. The community trust is 
the favoured form of legal entity within most provinces with the exception of the Northern Cape and Gauteng provinces which have a higher level of common property association (CPA). While the study has found that community and committee meetings do occur on a regular basis, only half of the respondents felt that report backs from the management committee were regularly carried out. Further, $68 \%$ of the land reform beneficiaries were not aware whether the total land grant funds had been utilised and almost $30 \%$ of the respondents did not know what type of land management structure had been adopted. This is an important issue since clear awareness of a project's governance structure, as reflected by beneficiaries' knowledge of the rules of the "trust" governing the project, was found to be an important determinant of project success.

The land reform programme is concerned with the regeneration of an agrarian economy, of which agriculture, whether as for subsistence, exchange or as a source of employment, is an important component. Land reform beneficiaries seem to be comparatively well endowed with agricultural resources. Provincial differences are quite marked in some instances - for example, while the average plot size owned or used by households in the Provinces of Mpumalanga, the Free State and the Northern Province exceeds 120 ha, in KwaZulu-Natal, the Northern Cape and the Western Cape it is less than 15 ha. With respect to the ownership of livestock, some $39 \%$ of surveyed households own large stock (excluding poultry). It is interesting to note however that only $10 \%$ of the sample had either bought or sold cattle over the past year, and only $4 \%$ had bought or sold poultry. This indicates subsistence rather than commercial use of these assets. Just less than two-thirds of households in the survey sample own agricultural equipment, which appears high. Interestingly, female-headed households tend to have a greater tendency towards agricultural equipment ownership than do male-headed households.

A total of 118 projects were identified in the 86 communities that were enumerated, with average of 1.4 projects per community. Just over $35 \%$ of the households that were surveyed had at least one household member participating in these projects, with an average of 1.2 people per households amongst that that were participating. Roughly half of these communal projects are generating an income, 
although few are making any profit. This is not unusual for enterprises that are only 2-4 years old, but does suggest the need for support from institutions specialising in micro-enterprise support, as well as from the Department of Agriculture. Nonetheless, although many projects do not yet show any signs of economic potential, fourteen projects (or about $15 \%$ of the total) were characterised by very high profits, generating a median income for the typical beneficiary of R 10000 per year. This would not only provide a very favourable return on the land acquisition subsidy of $\mathrm{R} 16000$ but also be more than sufficient to lift beneficiaries out of poverty.

Although only $13 \%$ of respondents indicated that there had been moderate or severe conflict in the community over the past year, only half of the sample said that people in the community trust one another over most things. It is also noteworthy that over $80 \%$ of land reform beneficiaries had expected to plant crops and to generate an income from agriculture, although only $22 \%$ actually realised this expectation. More than $90 \%$ of land reform beneficiaries expected better services and homes after the land reform process, and only $15 \%$ felt that these expectations had been realised. Lastly, 29\% of the respondents described themselves as being unhappy or very unhappy with the land reform process, suggesting that despite the high level of unrealised expectations, in 1999, beneficiaries were broadly satisfied with the process.

Finally, the data show that the land reform programme has largely succeeded in reaching its target of the rural poor and has not been hijacked by the rich and powerful. Regression analysis undertaken by Deininger and May (2000) supports the evidence that land reform targets labour-abundant households who are poorer than the average but have higher level of productive agricultural assets (mainly animals). Household income and expenditure emerge as being highly significant and negative determinants of participation in the land reform programme. It was also found that observable beneficiary characteristics had not been an important determinant for the economic success of specific land reform projects. Finally, women-headed households are at least proportionally represented in the land reform programme, although it does seem that maleheaded households have access to larger plot sizes on average. The educational level of heads of land reform households is lower than 
the national average. It can be concluded from this that, if land reform can be made to be effective, it has considerable potential to contribute to overcoming the legacy of apartheid and to a sustainable reduction of rural poverty.

\section{CONCLUSION}

The South African land reform programme has developed as a process of learning by doing. The first five years of the postapartheid period have witnessed the establishment of an administrative infrastructure for land transfer, and the gradual adaptation of the initial programme design to the requirements of the real world. All of these, together with the change of government in 1999, make this an ideal moment to take stock and try to assess the lessons from the past for future implementation of land reform in this country. The collection of a comprehensive monitoring and evaluation data set has made such analysis possible.

Analysis of the M\&E data from the Quality of Life survey undertaken in 1999 shows that there has been an improvement in both the performance and impact of land reform since the previous monitoring activities undertaken in 1998. This has taken place in a number of ways, with an increased rate of delivery, targeting of the most poor has taken place and there is less evidence of institutional problems than was found in the 1998 study. In addition, both agricultural and non-agricultural production is occurring and services delivery to land reform beneficiaries seems better than to the rural population as a whole.

However, poverty levels among land reform beneficiaries remain high, as do the levels of dissatisfaction that they express. Many projects do not yet show any signs of economic potential and many participants in the land reform projects have little knowledge of the management of the project and how funds have been utilised. This opens opportunities for corruption and the misuse of community funds. It is recommended that the land reform programme continue to be supported, and perhaps even expanded, but that consideration be given to the redesign of some elements of the programme. Areas for attention include simplifying the administrative procedures that are followed, increasing the flexibility of the programme to allow for larger grants and linking to other programmes of livelihood 
support and service delivery and finally. Finally, ways of targeting sub-groups of the rural poor whose current participation in the land reform is limited should receive specific attention.

\section{NOTES}

1 The conventional set of money-metric poverty measures developed by Foster, Greer and Thorbecke (1984) have been calculated using data derived from Stats SA (1997), Income and Expenditure Survey, 1995.

2 Derived from DLA records and the M\&E sample frame.

3 The system is explained in the following memoranda: Coleman, G. (25/10/1995), A reporting structure for the M\&E System in the Directorate of Land Reform Information and Evaluation: First Thoughts; Coleman, G. (October, 1995), Implementing the M\&E System in the Directorate of Land Reform Information and Evaluation: Third Thoughts; Coleman, G. (27/10/95), Report on Work at the Directorate of Land Reform Information and Evaluation, Department of Land Affairs, 1-28 October, 1995; Coleman, G. (18/10/95), Sampling, confidence levels and precision in the M\&E system of the Directorate of Land Reform Information and Evaluation, First Thoughts; Coleman, G. (25/10/95), Monitoring and Evaluation Information as a Public Resource: First Thoughts.

${ }^{4}$ Baulch and Hoddinott (2000) provide a useful review of examples of panel studies from developing countries.

5 The poverty gap ratio for the ultra-poor increases from 0.186 to 0.476 .

${ }^{6}$ Land access implies that the household either owned the land, or had been given the right to use the land by a land regulation authority.

7 Although it is recognized that not all land reform beneficiaries are African, and that not all beneficiaries are rural, for the purposes of comparison with the Statistics South Africa's October Household Survey, only this group have been selected.

\section{REFERENCES}

ANC: 1994, The Reconstruction and Development Programme: A Policy Framework (Umanyano Publications, Johannesburg).

Baulch, R. and J. Hoddinott: 2000, 'Economic mobility and poverty dynamics in developing countries', Journal of Development Studies, p. 366.

Carter, M.R. and J. May: 1999, 'Poverty, livelihood and class in rural South Africa', World Development 271, pp. 1-20.

Chambers, R.: 1988, 'Sustainable rural livelihoods: a key strategy for people, environment and development', in C. Conroy and M. Litvinoff (eds.), The Greening of Aid (Earthscan, London).

Cornia, G.A. and F. Stewart: 1995, 'Two errors of targeting', in D. Van de Walle and K. Nead (eds.), Public Spending and the Poor: Theory and Evidence (Johns Hopkins Press, Baltimore). 
Deininger, K. and J. May: 2000, Is There Scope for Growth with Equity: An Initial Assessment of Land Reform in South Africa. Policy Research Working Paper, No. 2451, World Bank, Washington, DC.

Dreze, J. and A. Sen: 1989, Hunger and Public Action (Clarendon Press, Oxford). Foster, J., J. Greer and E. Thorbecke: 1984, 'A class of decomposable poverty measures', Econometrica 52(3), pp. 761-766.

Government of National Unity: 1994, RDP White Paper Discussion Document (Government Printers, Pretoria).

Grosh, M. and J. Munoz: 1996, A Manual for Planning and Implementing the Living Standards Measurement Study Survey. Living Standards Measurement Study Working Paper No. 126, World Bank, Washington DC.

Klasen, S.: 1997, 'Poverty and inequality in South Africa: An analysis of the 1993 SALDRU Survey', Social Indicators Research 41, pp. 51-94.

Levin, R. and D. Weiner: 1997, No More Tears, Struggles for Land in Mpumalanga, South Africa (World Press, Trenton NJ).

Lipton, M., F. Ellis and M. Lipton (eds.): 1996, Land, Labor and Livelihoods in Rural South Africa, 2 vols (Indicator Press, Durban).

Lipton, M. and M. Ravallion: 1997, 'Poverty and policy', in J. Behrman and T.N. Srinivasan (eds.), Handbook of Development Economics, Vol 3 (North Holland, Amsterdam, pp. 2553-2658).

Stats SA: 1997, The October Household Survey (Statistics South Africa, Pretoria). Stats SA: 1995, Income and Expenditure Survey (IES).

Van Zyl, J. and J. Kirsten: 1997, 'Economic empowerment in South Africa', in L. Haddad (ed.), Achieving Food Security in Southern Africa: New Challenges, New Opportunities (International Food Policy Research Institute, Washington, D.C).

Van Zyl, J., J. Kirsten and H.P. Binswanger: 1996, Agricultural Land Reform in South Africa: Policies, Markets, and Mechanisms (Oxford University Press, Cape Town).

School of Development Studies

Julian May

Memorial Tower Building

University of Natal

King George V Ave

Durban, 4001

South Africa

Department of Land Affairs

Private Bag X833

Thildé Stevens

Pretoria, 0001

Annareth Stols

South Africa 